\title{
Remembering Life under Apartheid with Fondness:The Memoirs of Jacob Dlamini and Chris van Wyk
}

\author{
David Medalie
}

In memory of Chris van Wyk (19 July 1957 - 3 October 2014)

\begin{abstract}
A number of works of non-fiction written in the post-apartheid period reflect on childhood and adolescent experiences during the apartheid years. This paper looks at three of them: Jacob Dlamini's Native Nostalgia (2009) and Chris van Wyk's two memoirs, Shirley, Goodness and Mercy (2004) and Eggs to Lay, Chickens to Hatch (2010). Dlamini's memoir describes his childhood in Katlehong, while van Wyk's deal with his early experiences in Riverlea. These memoirs are unusual in that, while they do not hesitate to expose the injustices of apartheid, they nevertheless seek to convey the persistence of normality and the "ordinariness" of family and community life within the abnormality of apartheid. This paper considers the implications of "fondness" or nostalgia in all three memoirs, as well the ways in which Dlamini and van Wyk present non-deterministic conceptions of identity and pay tribute to powerful matriarchal figures. The use of humour in Shirley, Goodness and Mercy and Eggs to Lay, Chickens to Hatch is also analysed. Finally, some possible reasons are given as to why van Wyk's memoirs seem to have been spared much of the criticism which has been directed at Dlamini's.
\end{abstract}

English in Africa 43 No. 3 (December 2016): 43-60

DOI: http://dx.doi.org/10.4314/eia.v43i3.3 


\section{KEYWORDS}

Jacob Dlamini, Chris van Wyk, Katlehong, Riverlea, memoir, apartheid, post-apartheid, nostalgia, identity, matriarchy, humour

Nadine Gordimer famously and epigrammatically described apartheid as "above all a habit; the unnatural seems natural" (Gordimer, "Living in the Interregnum" 266). A great deal of writing about apartheid has sought to record this naturalization of the unnatural; to expose the horror behind the façade of ostensible normality. This impulse has provided the shape and tone of many varied narratives, including Gordimer's own first novel, The Lying Days, published in 1953.

As Hedley Twidle points out, in the post-apartheid period, the ascendant literary form has been non-fiction rather than fiction:

For, whereas during apartheid, it was the domain of literary fiction, specifically the short story and the novel, which provided the most acclaimed versions - or to use Ezra Pound's phrase, the news that stayed news - of this Southern African society, in the decades post-apartheid [...] the most significant literary production is judged to have shifted decisively into the realms of non-fiction.

(Twidle 8)

Many of these non-fictional works of the post-apartheid period describe the experience of growing up during the apartheid years; and, even in these "realms of non-fiction," the revelation of the habitual nature of apartheid remains a recurring focus. A recent example is Ufrieda Ho's Paper Sons and Daughters (2011), which, like Darryl Accone's All Under Heaven (2004), details the story of a Chinese family during the apartheid years and, more generally, the lives of the Chinese community in South Africa during that period. Ho describes the process whereby she gradually came to understand the "unnaturalness" of the community in which she grew up - a community that, having been forced to occupy a "state of in-betweenness," found it strategic to exploit the resultant "fog of invisibility" (Ho 186). This meant ignorance of and even a form of passive acquiescence in the very system which oppressed the Chinese in South Africa and imposed upon them a life of "shadows and scars" (4). As an example of this, Ho describes the contrast between the response to 
the massacre in Tiananmen Square in 1989 and what was happening in South Africa at the time:

We identified more with this struggle far away without even knowing that there was a man called Nelson Mandela fighting for freedom. As we pasted more newspaper over the statue [a papier mâché replica of the goddess of democracy] in solidarity with a cause in another world, we did not know what was happening in our own backyard. It was our socialised norm; we could see China burning and the Berlin Wall falling, but we were still bricked in by the lies and secrets of apartheid.

As is typical of such narratives, Ho comes to recognize and, in turn, to expose the "abnormality" hidden by and within the "socialised norm" of apartheid society, and thus to contribute in her own way to dislodging the "lies and secrets of apartheid."

In recent years, however, several memoirs have been published that follow another trajectory and pursue a different agenda in relation to the apartheid past and to experiences of childhood and adolescence during apartheid. These, in looking back at those years, are concerned rather to represent the survival of "ordinariness" within the experience of living under apartheid, and, particularly, in township life. The emphasis here is not on how apartheid contaminated any hope or form of normality through the imposition of its egregiously aberrant practices; instead, these memoirs seek polemically to demonstrate the persistence of normality as an expression of the extraordinary resilience of specific communities. They are works of cultural and historical retrieval. Most notable amongst them are Jacob Dlamini's Native Nostalgia, published in 2009, which describes and reflects upon Dlamini's childhood and adolescence in the East Rand township of Katlehong, and Chris van Wyk's two acclaimed memoirs, Shirley, Goodness \& Mercy, published in 2004 and re-issued in 2014, and Eggs to Lay, Chickens to Hatch, published in 2010, which focus largely on van Wyk's early life in Riverlea, a Coloured township in Johannesburg.

What these memoirs have in common is their evocation of the richness of a life lived despite apartheid and their refusal to represent township life solely in terms of deprivation and dearth. Memory in them 
has therefore a different configuration and an explicitly revisionist function. The more traditional apartheid memoir uses the pathos which depictions of suffering and injustice elicit as a way of recalling the humanity of those whom apartheid has dehumanized. It finds a certain moral and historical justification in the exposure of victimhood, even if, as in Mark Mathabane's Kaffir Boy (1986), the victim then goes on to overcome triumphantly the uncongenial circumstances of his or her early life.

The memoirs of Dlamini and van Wyk, by contrast, without ever denying the existence of suffering, oppression and poverty, reveal positive experiences within the apartheid childhood and adolescence and, in van Wyk's case, humour - to restore agency to their subjects. These are the result of powerful bonds of community and family and constitute what Judith Lütge Coullie calls an "ethics of memory":

the emphasis, in Native Nostalgia, on positive aspects of relationships amongst members of the community and Dlamini's love for his mother (to whom the book is dedicated) is an ethical use of memory for it denotes - and promotes - caring and strengthens bonds of mutual consideration in the representation of memory.

(Coullie)

As in more conventional recollections of those years, the aim is to endow those who have been dehumanized with a fuller humanity, but here - as in van Wyk's memoirs - it is achieved through the discovery of unexpected, even miraculous, spiritual plenitude in individuals and robust community relationships within conditions of stark social deprivation.

Dlamini's memoir, not surprisingly, has been considered highly controversial and has been attacked because it is perceived as diluting or even excusing the suffering of black people under apartheid. Eric Miyeni, for instance, writing in The Sowetan, is under the impression that the core argument of Native Nostalgia is that "growing up in apartheid-designed townships was fun." So repugnant is this to Miyeni that he declares: "I find [this premise] so sickening I decided never to read [the book]" (Miyeni). He goes on to conclude that "[t]he only purpose it serves is to reduce white South Africa's guilt over its past transgressions" (Miyeni). In a more thoughtful criticism, Sandile 
Memela also accuses Dlamini - as well as several other prominent black writers - of reactionary tendencies, amounting to a form of "new black literary self-sabotage" (Memela). Such writers, he suggests, write to "gain white approval" and are therefore in danger of "being considered creative Uncle Toms who please white audiences at the expense of black integrity and history" (Memela).

These disparaging remarks are based upon a fundamental misunderstanding or misconstruing of the intention underlying memoirs such as Dlamini's and van Wyk's - although, as far as I can ascertain, van Wyk's have not been subjected to similar criticisms, and I shall consider some of the possible reasons for that towards the end of this paper. Neither Dlamini nor van Wyk comes close to suggesting that apartheid was anything but morally reprehensible, nor is there any evidence of a desire to placate or exonerate white people. Dlamini, aware of the potential contentiousness of his subject matter, anticipates the accusation that his memoir is insufficiently denunciatory in relation to apartheid:

There are people for whom the present is not the land of milk and honey, the past not one vast desert of doom and gloom, and the ancient past not one happy-go-lucky era. For many, the past is a bit of this, the present a bit of that and the future hopefully a mix of this, that and more. For these people, among whom I count myself, there is a conundrum that cannot be got rid of easily by the lazy evocation of labels such as 'sell-outs' or 'self-hating blacks'. The conundrum is this: What does it mean for a black South African to remember life under apartheid with fondness? What does it mean to say that black life under apartheid was not all doom and gloom and that there was a lot of which black South Africans could be, and indeed were, proud? Only lazy thinkers would take these questions to mean support for apartheid. They do not. Apartheid was without virtue.

(Dhlamini, 13-14)

Dlamini deliberately uses clichés in his rendering of reductive attitudes towards South African history and glib representations of its sociopolitical realities: the present a "land of milk and honey," the past a "vast desert of doom and gloom." In doing so, he shows that among the main targets of his polemic in Native Nostalgia are triteness, 
oversimplification and the failure to recognize the complexity of life in South Africa - both during the apartheid period, and in the present. He inveighs against what he calls "a master narrative of homogenous black suffering" (18) which, he argues, "blinds us to a richness, a complexity of life among black South Africans, that not even colonialism and apartheid at their worst could destroy" (19). In insisting, as he does, that "South Africans are not agreed on the meaning of their past" (6), Dlamini is arguing for a recognition of the multivalent and variegated nature of both memory and history. In place of homogenizing or totalizing tendencies, he speaks of the particularity, even the idiosyncrasy of one's relationship with the past. Using a suggestive paradox, he describes his memoir as a "fractured whole" (62) which presents "fragments, shards of memory" (22).

Behind the more general polemic of Native Nostalgia, including the desire to refute the perception that townships are merely "zones of deprivation that can only ever be defined in a negative sense, in terms of what they do not possess" (105), lies a very personal urgency: Dlamini's determination to give value to the life of his late mother. He speaks of Katlehong as "a place filled with embodied memories" (154), but, more than anyone else, it is in the figure of his mother that these memories are embodied. For all its academic and theoretical aspects, Native Nostalgia is a work of tender filial homage. It is also an act of literary emancipation, for Dlamini wishes, so to speak, to rescue his deceased mother, a woman whose beliefs he describes as constituting "political gradualism and religious conservatism" (22), from both the accusations and the neglect of history. He seeks to restore to his mother her status as a moral agent and arbiter during the apartheid years and holds her up as the primary example of a stance that, within a system "without virtue" (13), found it possible to make significant ethical choices - and to insist that her son should do the same.

Dlamini's homage to his mother is not without its contentious aspects, for during the turbulent decades of the 1970s and 1980s, she was anything but an iconoclast: she worked within existing township structures and, although she had little formal schooling herself, she believed implacably in the importance of education, even the Bantu Education which was available to her son: 
For my mother, there was no such thing as liberation before education. That is why she did not believe in class boycotts [...]. To remember my mother's insistence on education is to remember that there were sharp divisions within the black community about how to struggle for freedom. For someone like my mother, whose lack of education had limited the job opportunities available to her, education was key.

The argument that there were different strategies in the struggle for freedom is used to validate the life and choices of Dlamini's mother, even as it emphasizes once more the multiplicity of narratives and options within the story of black liberation. Dlamini conspicuously refuses the tendency identified by Kharnita Mohamed and Kopano Ratele for "Black postapartheid subjects [to] remake themselves through the repudiation of their parents' attitudes to apartheid," accompanied by a "willingness to nurture political consciousness against the family's silences" (Mohamed \& Ratele 290).

Memela and Miyeni are not incorrect in recognizing that a crucial part of the polemic at work in Native Nostalgia is an attack on what Dlamini perceives as the inadequacies of the ANC government and its policies. Memela accuses Dlamini and other black writers of "fall[ing] into the trap of rubbishing the achievement of freedom and democracy" (Memela), while Miyeni accuses two books which he declares he will not read - Native Nostalgia and Anton Harber's Diepsloot - of "creat[ing] barriers to black success" and "weaken[ing] our struggle for black economic freedom" (Miyeni).

The merits of the criticisms Dlamini makes of post-apartheid society - both in his memoir and in his trenchant journalism - lie beyond the scope of this paper. But Memela and Miyeni err in thinking that the inevitable corollary to disillusionment with the present is a romanticizing of the past, and to assume that this is what Native Nostalgia does. To put it differently: they have misunderstood the significance of nostalgia as it is used in the memoir, for it is not - as Miyeni seems to think - a deeply conservative assessment of the past which encloses it glibly within a cocoon of satisfaction. Dlamini himself tackles this issue in his memoir, insisting that nostalgia "does not have to 
be a reactionary sentiment" (Dlamini, 17); and he takes great care to distinguish, following Svetlana Boym, between "restorative" nostalgia and "reflective" nostalgia (17). The former is an unreflecting response which neither interrogates the past nor the need for the past in the present. Instead, it uses the past uncritically to satisfy the ideological imperatives of the present. The latter, however, has a critical edge - as Dlamini says, it "does not take the past for granted," nor does it "seek to monumentalise it" (18). Reflective nostalgia is akin to what may also be termed a "critical" or "evolved" nostalgia (Medalie, "Uses of Nostalgia" 41).

The two kinds of nostalgia treat memory in fundamentally different ways: restorative or unreflecting nostalgia requires the past to make itself an instrument of the present, to pander to and appease it, and to reinforce the master narratives which contemporaneity favours, while reflective or critical nostalgia, in recognizing the "constructedness of memory" (Medalie, "Uses of Nostalgia" 41), uses the past to trouble generalizations, to bring ironies to the surface, and, ultimately, to insist that history has an integrity beyond the urgencies of the present. Dlamini makes this an explicit part of his polemic in a passage in which he repudiates the notion that "the act of remembering, the work of memory" may be "an innocent act" (Dlamini, 109):

It seems to me that in a time when to think positively about black life under apartheid is, as Walter Benjamin would say, to 'brush history against the grain', the act of remembering has itself acquired a political meaning. To remember is a political act, for it means to refuse to buy into the annihilation of the moral agents whose primary world was and still is the township.

All three memoirs under discussion here, in their determination to present a picture of life under apartheid that is not restricted to loss and suffering, are examples of "brush[ing] history against the grain." All establish a link between this way of responding to history, on the one hand, and, on the other, agency and a capacity for decisive moral action in the individual (especially evident in strong matriarchal figures). And all three relate this empowerment of communities and certain community members to creativity and the imagination. 
A critical or evolved nostalgia may function as a form of "imaginative transformation or reinvention" (Medalie, "Uses of Nostalgia" 35), since it requires a dynamic engagement with the past and an acceptance of fluidity in the relationship between past and present. Significantly, the memoirs of Dlamini and Van Wyk - which I believe to be rich examples of this form of nostalgia - make much of the possibilities of transformation and reinvention. For Dlamini, the township in which he grew up is also a site of the imagination: "Katelhong is more than just a township made up of houses and basic amenities. Katlehong is also a world that exists in the imagination, a world where the metaphorical is as important as the material" (107). The notion that Katlehong "is also a world that exists in the imagination" is empowering because it means that its meanings are neither fixed nor dictated by others, but may be made and remade. This is apparent in what is perhaps the most surprising aspect of Native Nostalgia, which is the nostalgic affection Dlamini feels for Afrikaans, a language which has frequently been characterized as the language of the oppressor. But that view of the role played by Afrikaans and its legacy is akin, for Dlamini, to a "master narrative" of linguistic coercion, and, not surprisingly, he disputes it:

[Afrikaans] might have been the language of the oppressor at some level, the language of order and exclusion. But it was also the language of colloquial expressions and the mode in which my mother, her friends and siblings exercised their own form of exclusionary politics.

To say that Afrikaans is the language of black nostalgia par excellence is to strip Afrikaans of its racialised baggage. It is to say that there are many more ways of resisting the depredations of power.

In other words, Afrikaans in the Katlehong of his early life has acquired its own meanings - some shared widely in the community, some more esoteric. Seen in that light, Afrikaans as represented in Native Nostalgia is almost an allegory for what Dlamini is determined to locate in his memories: a cluster of meanings to make his own, privately and perhaps 
idiosyncratically, in contrast to the "socialised norm" of which Ufrieda Ho speaks (118).

An important target of Dlamini's polemic is determinism particularly the kind that links people ineluctably to the material conditions of their lives. Finding positive aspects to his childhood and adolescence in Katlehong does not mean, he writes, that "there was no poverty, crime or moral degradation. There was. But none of this determined black life in its totality" (Dlamini, 19). Declaring that "it would be wrong to think of townships only in terms of their economic function" (105-106), he goes on to argue that the complexity of class relations and economic practices in Katlehong "means acknowledging that material relations do not determine everything" (106). What this shows is that Dlamini's aim extends beyond the desire to rescue his deceased mother from charges made against her and others of her generation. He is concerned also to redeem a certain conception of identity, one in which the individual is not defined by history and circumstance. Instead, he or she lives life more unpredictably and therefore, according to this view, more fully.

This perception of the human spirit as not bound by social constructions of identity is evident also in van Wyk's memoirs; and, as in Native Nostalgia, it finds expression in part in emphasizing the transformative power of the imagination in the construction of memory. Towards the beginning of Eggs to Lay, Chickens to Hatch, van Wyk explains that "[w]riting a memoir is a little like travelling into your own past. Unlike science fiction, you can't change the past. But, like science fiction, it does have its own magic" (4). One may argue that all memoirs are acts of reinvention rather than mimetic transcription and may therefore be regarded as tending inevitably to "change the past"; but this opens up a wider debate about the status of "truth" in non-fictional recollections, which cannot be explored in any detail here. What is telling, however, is that, whether the past has been changed or not, van Wyk associates the journey into the past with magic; and in his memoirs, magic emanates from a number of sources and expresses itself in several contexts: these include the seductive power of words, stories and reading, playfulness, humour (especially when it is irreverent) and the apparently limitless ability of matriarchs to intervene in difficult situations and thus ensure the resilience and sustainability of the community. The power of magic also intimates the same non- 
deterministic attitude to selfhood that Dlamini argues for, since it may have the effect of interrupting causality, particularly imputed causal relationships between the social environment and the people who inhabit it.

A very important commonality discernible in Dlamini's and van Wyk's memoirs is the emphasis on powerful women. Dlamini, as has been suggested, makes homage to his deceased mother the core of Native Nostalgia. In van Wyk's memoirs, too, the women (especially the eponymous Shirley, van Wyk's mother) tend to be assertive and resourceful, and to act as agents of social cohesion, whereas the men are frequently represented as feckless. "Mothers have special powers" (van Wyk, Shirley 83), declares the young Chris in the chapter entitled "Supermen and Superwoman," in which he recounts how his mother came to his rescue and intervened decisively when he was wrongly accused by the father of one of his friends of stealing a comic book. Significantly, this is the same chapter in which he recalls the reaction of the community to the murder of the then prime minister, Hendrik Verwoerd. The effect of including these two episodes in the same chapter is to contrast the power of the mother (Superwoman) with the power of patriarchy (Supermen), including that of the most notorious apartheid ideologue, and to show how even these seemingly invincible figures may be undermined by the sly and subversive power of humour.

Throughout the chapter the assassination is represented humorously and bathetically. The young Chris introduces it as follows:

So one day, in 1966, a man gets knifed and dies and it's so serious that we all get sent home from school early the day it happens. This is a real treat! We're caught so off-guard that we almost don't know what to do on this unexpected holiday.

As is frequently the case in these memoirs, the humour turns childhood naivety into a quality which the reader is almost certain to find beguiling; and, once beguiled, he or she is enticed into laughter; and then it is almost impossible to be solemn about anything, including the assassination of Verwoerd. The ignorance of the child becomes its own form of wisdom. Later Chris's father denounces Verwoerd as "an arsehole, an idiot," despite just having explained to the boy that the prime minister is not called $D r$ Verwoerd because he is a medical doctor, 
but because "he went to university for many years and [...] studied hard and he's clever" (85), a paradox which the young Chris finds perplexing. But for the reader the father's contemptuous denunciation of the prime minister is less powerful than the child's perspective, for it is the child in whose hands the weapon of humour is placed; and in these memoirs humour is potent magic.

In "A Panoramic View," an episode from Eggs to Lay, Chickens to Hatch in which the young Chris decides that he is a communist, the representation of apartheid as an anti-life force turns yet again on humour, or the lack thereof. Chris listens to a programme on the radio called Forces' Favourites, in which people send messages to young white men who are fighting on the border:

Then the Prime Minister, John Vorster, speaks. He says: 'The communists will never take over this country because we have God on our side...'

He has a sad voice with no sense of humour. He sounds like a man who has never been a boy, never played a prank, never held a frog in his hands, never liked a girl, never shared a secret with a best friend. He sounds as if he were born to warn others about the communists.

(Van Wyk, Chickens 133)

These accusations against Vorster seem ludicrously trite. But in the wider context of the memoirs, they are not. The "sad voice with no sense of humour" is at odds with the moral texture of the memoirs themselves, in which humour speaks of a non-deterministic ability to rise above incumbent circumstances, to find joy wherever it resides, and to lead a life worthy of nostalgic recollection. The sad, humourless voice of the prime minister expresses synecdochically the essential morbidity of apartheid and hence its eventual death knell.

The crucial connection between matriarchal power and humour is rendered explicit in a poem by van Wyk entitled "My Mother's Laughter," which he quotes in Shirley, Goodness \& Mercy. Describing his mother's laughter as "sounds that slaughtered the sadness" (Shirley 122), the speaker of the poem associates the mother's laughter, firstly, with the kind of subversiveness which mocks pomposity and solemnity and, significantly, is associated with childhood and play: 


\begin{abstract}
On Sundays my mother's laughter swept the sombre crosses off the shoulders of the churchgoers flung us into the streets with our white shirts pockmarked with the talismans of tomato sauce and the brooches of beetroot.
\end{abstract}

The fifth stanza reiterates another important connection - that between laughter and the ability to survive uncongenial circumstances:

Throughout her life my mother laughed
as she still does today
And even though there was much to cry about
as there is even now
so seldom does she weep
that I am forced to put her tears in parentheses

This stanza, almost prosaic in its simplicity, and containing only one instance of figurative language ("I am forced to put her tears in parentheses"), may be regarded as a pithy expression of the interplay between sorrow and solace, dearth and abundance, which informs these memoirs. The admission that "there was much to cry about" gestures towards the harshness of life under apartheid; but the mother's laughter, which never ceases, since she laughed "[t]hroughout her life.../as she still does today," is a force greater than the sorrows and setbacks imposed by the conditions the family lives under. In the metaphor used here, the mother's weeping is shown to be of little importance: the sentence that articulates their lives does not need it in order to be syntactically meaningful and complete.

One question that arises from a comparative reading of these memoirs relates to the responses to them. As indicated above, van Wyk's have not - as far as I am aware - been subjected to the denunciations which followed the publication of Native Nostalgia. Yet van Wyk is no less determined to demonstrate the survival of community and family life under apartheid, and his depiction of those 
bonds is, if anything, more tenderly nostalgic than Dlamini's. Why, then, have his memoirs been spared those criticisms?

Although my reflections on this question are necessarily speculative, it seems to me that there may be two reasons. The first has to do with the fact that humour is pervasive in Shirley, Goodness \& Mercy and Eggs to Lay, Chickens to Hatch, while it is largely absent in Native Nostalgia. Humour is frequently experienced as a form of invitation, a collaboration or even an act of complicity between the humorist and his or her readers or audience, even when it is darkly subversive. Van Wyk's memoirs contain pain, guilt and grief, and there are also disturbing descriptions of cruelty, especially from adult authority figures towards children; but, as has been suggested, the humour is indefatigable. As we have seen in the episode which recalls the assassination of Verwoerd, humour is also used seditiously to undermine the master narratives of apartheid through irreverence and bathos:

[Van Wyk] was determined to make the point that disadvantaged people are capable of living lives that refute the diminished identities attributed to them by officialdom. He wanted to show that people are not less than fully human simply because they are treated inhumanely. And that is what the humour in Shirley, Goodness \& Mercy and Eggs to Lay, Chickens to Hatch speaks of: a capacity for resilience and an irrepressible appetite for life, even in straitened circumstances.

(Medalie, "Introduction" xiv)

It is possible, therefore, that the humour disarmed potential critics; or that it made the nostalgia seem less combative than Dlamini's.

Another reason may be that, unlike Native Nostalgia, which, as we have seen, is scathingly critical of aspects of post-apartheid society, van Wyk's memoirs do not engage at all with post-apartheid South Africa, except to represent it as the culmination of a long struggle for freedom. The disillusionment with the present, that, in Dlamini's memoir, provides an added complexity to the nostalgia for the past, is absent in Shirley, Goodness \& Mercy and Eggs to Lay, Chickens to Hatch. In fact, the former offers an incremental movement from youthful naivety in the young Chris, to the dawning of political awareness in him, his becoming an activist and embracing a Black Consciousness ideology, and, finally, to his attaining citizenship in a democratic South Africa. 
This trajectory is represented in part as a journey of reading and learning. In a chapter in Shirley, Goodness \& Mercy which deals with the return from exile of Es'kia Mphahlele, van Wyk describes a literary event he attended in Braamfontein:

The hall is packed with writers, black and white. Everybody is reading out papers and saying things about literature that I didn't even know existed: negritude this, black consciousness that, Achebe this and Ngugi that, discourse this, of course that. Colonialism, liberation, Frantz Fanon .... Real school has finally started for me.

(van Wyk, Shirley 269)

The iniquities of apartheid education and the National Party government's distorting of history - permitted and thus perpetuated during the young Chris's years at school by several Coloured teachers and headmasters - are described at length in the memoirs; they amount to an inauthentic learning, the imposition of a false consciousness. But here, as van Wyk's eyes are opened to an alternative history, new writers and different ways of reading, he declares, with a ringing rhetorical flourish, that "[r]eal school has finally started for me."

There is a clear line that leads from this revelation, this acquisition of unassailable knowledge, to the new South Africa, as suggested by the penultimate episode in Shirley, Goodness \& Mercy, "A Miracle and a Wonder." Here the adult Chris explains to his young son what a miracle is: "If something cannot happen, if it's impossible, but it does happen, that's a miracle" (308). The chapter concludes thus: "Miracle. Wonder. Call it what you will. On 27 April 1994 it happens for over forty million South Africans" (308). In the final episode, "The Stories Begin Again," van Wyk describes his continued engagement, in the post-apartheid present, with the community of Riverlea, and his determination to continue to tell his people's stories: "I decide to stay here. There are so many people in their eighties and nineties who have stories to tell. Stories that need to be told, stories that are a part of our history and which apartheid had made us believe should never be told" (309). Read together, these brief concluding chapters show the final movement of the narrative to be both a straight line and a circle: the straight line moves from the hardship of life under apartheid to the culminating "miracle" of 27 April 1994, while the circular line loops back to the past and to the 
undepleted power of origins and untapped stories. In simultaneously moving forward and circling back, the narrative makes nostalgia a means of entry into an accomplished present, but also a way of retaining the past in all its richness. In Dlamini's memoir the latter impulse is strongly present, but not the former. Unlike van Wyk, he uses the past to castigate the present; and therein, in the disillusionment thus conveyed, lies a crucial difference between his narrative and van Wyk's.

For decades, the apartheid memoir - whether in non-fictional form, or transformed, with strong autobiographical undertones, into fiction has been at least in part a story of painful loss. At the beginning of her first (and heavily autobiographical) novel The Lying Days, Nadine Gordimer quotes W. B. Yeats's "The Coming of Wisdom with Time":

Though leaves are many, the root is one;

Through all the lying days of my youth

I swayed my leaves and flowers in the sun;

Now I may wither into the truth.

The notion of "wither[ing] into the truth" suggests that there is a price that has inevitably to be paid in forgoing spurious knowledge or false consciousness. An unadorned truthfulness is gained through a severe paring down, but it comes only by renouncing the youthful expansiveness which is intimated in the line "I swayed my leaves and flowers in the sun." The extent of this loss is described by Gordimer's protagonist, Helen Shaw, in a wistful passage in which she considers the question of childhood as opposed to adult "reality":

It is amazing on how little reality one can live when one is very young. It is only when one is beginning to approach maturity that achievement and possession have to be concrete in the hand to create each day; when you are young a whole livable present, elastic in its very tenuousness, impervious in its very independence of fact, springs up enveloping from a hint, a memory, an idea from a book.

(Gordimer, Lying Days 94)

Like many other narratives that describe political awakening in relation to apartheid, The Lying Days suggests elegiacally what has to be shed in the process - and, as described here, it is considerable: the "whole 
livable present" of the young person's delighted responsiveness to an environment which has not yet been contaminated. This is not unlike the "fog of invisibility" (186) from which, almost six decades later, Ufrieda Ho had to emerge in order to recognize the full reality of apartheid.

Native Nostalgia, Shirley, Goodness \& Mercy, and Eggs to Lay, Chickens to Hatch are noteworthy in part for the ways in which they are written against the grain. Their distinctiveness enlarges our understanding of the possibilities of retrospection in the post-apartheid period and, more generally within the phenomenon of nostalgia itself, described by Dennis Walder as "that strange mix of individual and social desires that prompts the search for past experiences" (Walder, 935). Unlike many other memoirs and semi-autobiographical fictions, they do not require a renunciation of the past in order to make nostalgia reflective and memory ethical. Similarly, they do not find it necessary to delineate an estrangement between the child, limited by lack of awareness, and the conscientized adult. Instead these highly original, even idiosyncratic memoirs - necessarily so, since they refuse to generalize the apartheid years or represent them homogenously - lift their subjects out of victimhood and free them from determinism. Even as they place great value upon ordinariness, they rescue it from banality - in particular, what Susan Pearsall has called the "persistent banality that attaches itself to representations of South Africa under apartheid" (Pearsall, 96). Without romanticizing their communities' histories or being glib about suffering, they unearth in the past what Dlamini calls "souvenirs of the imagination" (62).

\section{WORKS CITED}

Coullie, Judith Lütge. "The Ethics of Nostalgia in Post-Apartheid South Africa." Rethinking History: The Journal of Theory and Practice, 3 December 2013. <http://dx.doi.org/10.1080/13642529.2013.858449>.

Dlamini, Jacob. Native Nostalgia. Auckland Park: Jacana, 2009.

Gordimer, Nadine. The Lying Days. London: Victor Gollancz, 1953. . "Living in the Interregnum." 1982. The Essential Gesture: Writing, Politics and Places. Ed. Stephen Clingman. London: Penguin, 1989. 261-84.

Ho, Ufrieda. Paper Sons and Daughters: Growing Up Chinese in South Africa. Johannesburg: Picador Africa/ Pan Macmillan, 2011.

Mathabane, Mark. Kaffir Boy: The True Story of a Black Youth's Coming of Age in Apartheid South Africa. New York: Macmillan, 1986. 
Medalie, David. "The Uses of Nostalgia." English Studies in Africa 53.1 (2010): 35-44.

—. "Introduction." Shirley, Goodness \& Mercy: A Childhood Memoir. By Chris van Wyk. Johannesburg: Picador Africa/ Pan Macmillan, 2014. xixvi.

Memela, Sandile. "The New Black Celebrity Authors." 2009. $<$ http://www.artlink.co.za/news article.htm?contentID=23536>.

Miyeni, Eric. "Defining Blacks by Past Misery Is Unfair." 2011. $<$ http://www.sowetanlive.co.za/columnists/2011/06/27/definingblacks-by-past-misery-is-unfair>.

Mohamed, Kharnita and Kopano Ratele. "Where My Dad Was from He Was Quite a Respected Man." Peace and Conflict: Journal of Peace Psychology 18.3 (2012): 282-93.

Pearsall, Susan. "Where the Banalities Are Enacted': The Everyday in Gordimer's Novels." Research in African Literatures 31.1 (2000): 95-118.

Twidle, Hedley. “'In a Country where You Couldn't Make This Shit up?': Literary Non-Fiction in South Africa." Safundi: The Journal of South African and American Studies 13.1-2 (2012): 5-28.

Van Wyk, Chris. Eggs to Lay, Chickens to Hatch: A Memoir. Johannesburg: Picador Africa/ Pan Macmillan, 2010.

- Shirley, Goodness \& Mercy: A Childhood Memoir. 2004. Johannesburg: Picador Africa/ Pan Macmillan, 2014.

Walder, Dennis. "Writing, Representation, and Postcolonial Nostalgia." Textual Practice 23.6 (2009): 935-46. 